LETTERS TO THE EDITOR.

[The Editor does not hold himself responsible for opinions expressed by his correspondents. Neither can he undertake to return, or to correspond with the writers of, rejected manuscripts intended for this or any other part of NATURE. No notice is taken of anonymous communications.]

\section{Genius and the Struggle for Existence.}

WiLl you allow me to supplement the excellent reply of Sir Oliver Lodge to your correspondent Mr. G. W. Bulman by a few remarks dealing more specifically with that gentleman's difficulty, which is one very widely felt, but is, I believe, founded on a misconception?

The words "useful" and "advantage" have two distinct meanings, the one referring to material the other to intellectual and moral results; and it is in the former sense only that they can be properly used in relation to natural selection or survival of the fittest. In that relation, physical results only are of value - those that tend to the preservation of life on occasions of stress and danger. In deciding whether any quality, physical or mental, is of value in this sense, Lloyd Morgan's admirable test should be applied- "Is it of survival-value?" If not, then it is not useful in the struggle for existence either to the individual or the race, unless it happens to be combined with other qualities which are, in an exceptional degree, of survival value. Now genius in all its varying manifestations is a quality which has hardly any relation to survival except an adverse one, and only in exceptional cases is of any material advantage to the race. The genius of the poet, of the writer, of the artist, even of the inventor, only occasionally benefits the race in its material struggle with other races, while it very rarely gives long life and an ample progeny to the possessor. Its use to him is solely the enjoyment of the exercise of his faculty of creating. Too frequently it is of no material use whatever to him, and he dies in poverty and neglect. The two races that have exhibited the highest manifestations of genius were the ancient Greeks and the Jews. But this genius did not advantage their respective races in the struggle for existence. Both of them became permanently subject races, and that they have survived at all is not due to their genius, but to their exceptionally fine physical qualities, their courage and their endurance.

As a matter of fact, the law of the survival of the fittest has almost entirely ceased to apply to civilised man, and the more civilised he is the less it applies. I thave already shown (in the chapter on " Human Selection" in my " Studies"), how, under a higher civilisation and a truer social system, it will be superseded by another law, which may be termed " the perpetuation of the fittest," and which will operate as automatically and as beneficially in improving the human race as natural selection has acted in improving the lower animals. At present, as Darwin himself fully recognised, it is not the best or the highest that survive, but a comparatively low type morally and intellectually, though in relation to our present very imperfect civilisation they may be held to be the fittest. It is, however, fitness to "succeed in life," as it is termed, not necessarily to survive; and this is indicated by the comparatively short lives of millionaires and of the inhabitants of cities, who are continually replaced by the sons of the less successful but more virile inhabitants of the rural districts. Alfred R. Wallace.

\section{The Holy Shroud.}

Prof. MELdola's notice from a truly scientific standpoint of Dr. Vignon's book, entitled "The Shroud of Christ," is not less interesting than valuable, but I think two difficulties which hardly fell within the scope of his article may also be raised. One struck me at once in examining the facsimile of the photographic negative plate of the Holy Shroud (facing p. I7). The body had been lying, of course, face upwards. I presume that if a corpse were thus placed on a stone slab, within a very few hours of death, the nates would be slightly flattened by pressure, but their normal roundness - as in a nude standing figurecaught my eye at once when examining the plate.

But a still more serious difficulty awaits Dr. Vignon. The shroud in shape has a general resemblance to an elongated bath-towel; on one half, smoothed out, the body was laid, and the other was neatly doubled over the head, and brought down so as completely to cover the feet. This mode of burial, so far as I know, was not usual among the Jew's at that date (the corpse being more or less wrapped up, as described in the raising of Lazarus). But passing over this point, for Dr. Vignon pleads that the arrangement was a temporary one (though, by the way, it would make the preservative myrrh and aloes much less effective), we find the authors of the four Gospels all use language which excludes any such arrangement of the so-called shroud. Matthew and

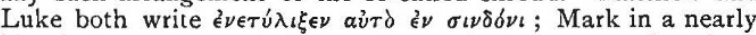
identical sentence substitutes the verb éveí $\lambda \eta \sigma \in \nu$. But both these words mean to wrap or to roll up, not to lay a sheet over (and under). John, in a rather more minute description,

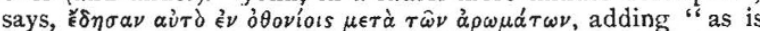
the custom of the Jews in burial." $\mathrm{He}$ also mentions bandages or body-cloths a second time, and a napkin bound about the head-which would have interfered with the photographic process. Dr. Vignon endeavours to elude the plain meaning of these passages, but, as it seems to me, he can only prove the genuineness of the shroud by rejecting the four principal witnesses to the facts of which it is supposed to be a record, a process which has a suspicious resemblance to sawing off the branch on which you are sitting.

T. G. BONnEy.

\section{The Herbarium of Ferrante Imperato at Naples.}

IN a recent issue of NATURE (vol. 1xvii. p. I8I), there is an account of a paper by Prof. B. Schorler on a history of systematic botany prior to Linnæus. In the list given of the most ancient existing herbaria, no mention is made of that of Ferrante Imperato, which is among the oldest extant. This ancient herbarium, the remains of which are preserved in the National Library of Naples, is also overlooked in the interesting paper, now in course of publication, in the Magyar Botanikai Lapok (Budapest, 1902), by Alfoldi Flatt Käroly, "Zur Geschichte der Herbare.'

An incidental notice of the herbarium of Ferrante Imperato was published by me in NATURE (vol. lxiii., November, 1900) in an article on Domenico Cirillo and the chemical action of light, in connection with vegetable irritability.

Ferrante Imperato, a Neapolitan simplicista, born in $155^{\circ}$, lived in Naples, where he died in 1625 . In those days, museums of natural history began to be formed in Italy, the most famous being those of Aldovrandi in Bologna, the museum of Pisa, where Andrea Cesalpino (1519-1603) taught, and the museum of Ferrante Imperato in Naples. In Ferrante's book, "Dell" Historia Naturale, Libri XXVIII.," edited by his son, Francesco Imperato, in 1599 , is given a picture of the museum at Naples. This museum, as the author says, contained "Natural plants artificially preserved, attached to the pages of special books, and besides, terrestrial, aquatic and flying animals : moreover, gems, marbles and divers stones, earths, minerals and metals, and preserved seeds and rare leaves, and extracts of divers earths and plants."

At the end of the sixteenth century, a Genoese nobleman, Giovanni Vincenzo Pinelli, formed in Naples a botanical garden or "Orto dei Semplici," in which many rare plants were collected under the care of Bartolomeo Maranta, of Venosa (who died in I570), Ferrante Imperato and Fabio Colonna (1567-1650), an active correspondence and exchange of materials being kept up with other collectors. As Imperato puts it in his book, "human sciences grow by communion among men; this do I say and confess because our studies and the matters of which we write have developed by the help of friends who have concurred in procuring for us things from divers parts of the world, or have been companions and fellow-labourers." Besides G. V. Pinelli, the chief helper in collecting foreign objects, and Maranta and Fabio Colonna, who lived in Naples, Imperato records among his correspondents Pietro Andrea Mattioli, of Siena (1500-1577), Melchiorre Guilandini, of Padua (I520-1589), Jacopo Cortuso, also of Padua (1513-1603), Ulisse Aldovrandi, of Bologna (I522-1605), Carlo Clusio, Kaspar Bauhin, of Bâle (1560-1624), and Colantonio Stelliola, "Professor of Recondite Sciences, to whom I have communicated the greater part of the discoveries made by me." One does not understand why some authors attribute the work of Imperato to this Stelliola.

The herbarium was perhaps the more important part of this Neapolitan museum, being contained in eighty volumes. The museum of Imperato got dispersed during the great plague of Naples in 1656, and only nine out of the eighty volumes of the 